\title{
Effects of Magnetically-Treated Water on Tomato Yield and Uptake of Heavy Metals Under Water Deficit Conditions
}

\author{
Kamorudeen Olaniyi Yusuf ${ }^{*}$, Modupe Ruth Baiyeri ${ }^{2}$ and Shakiru Ariyo Sakariyah ${ }^{1}$ \\ ${ }^{1}$ Department of Agricultural and Biosystems Engineering, University of Ilorin, P.M.B 1515, Ilorin, Kwara State, \\ Nigeria \\ ${ }^{2}$ Department of Agricultural and Bio-environmental Engineering, Kwara State Polytechnic, Ilorin, Nigeria \\ Corresponding author: kamaru.yusuf@yahoo.com
}

\begin{abstract}
This study was conducted to determine the effect of magnetically-treated water (MTW) on tomato yield and uptake of heavy metals by tomato fruit under water deficit conditions for possibility of food poisoning. The experiment was conducted twice for 85 and 114 days. The irrigation water was treated with magnetic flux density 319 gauss produced from electromagnet. The tomato seed (variety UC82B) was planted in 12 pots (1 tomato/pot) and irrigated with either MTW or non magnetically-treated water (NMTW). The treatments were $100 \%$ (1.0 litre), $80 \%$, and 60\% of available water $(A W)$ in a Completely Randomized Design (CRD) and each treatment was replicated 4 times. The yields and concentrations of Cadmium, Copper, Chromium, Iron, Lead, Manganese, Nickel and Zinc were determined from the tomato fruit. The mean yields of tomato with MTW for 100, 80 and 60\% were 275.8, 281.0 and $216.8 \mathrm{~g} /$ pot and the corresponding yields for NMTW were 200.1, 210.9 and $163.2 \mathrm{~g} /$ pot, respectively. The concentrations of Copper, Lead, Manganese and Iron in tomato for MTW at 100,80 and $60 \%$ were $0.03,0.02,0.12$ and $1.80 \mathrm{mg} / \mathrm{L}$ and the corresponding heavy metals for NMTW were 0.04 , $0.02,0.08$ and $1.60 \mathrm{mg} / \mathrm{L}$, respectively. The Zinc for $M T W$ was $0.01 \mathrm{mg} / \mathrm{L}$ but not detected for NMTW. Concentrations of Cadmium and Chromium were not detected for MTW and NMTW. Concentrations of all heavy metals in the tomato were below (FAO/WHO) permissible limits. MTW increased tomato yield and didn't increase uptake of heavy metals that could cause diseases to man. The technology is recommended for tomato production.
\end{abstract}

Keywords: heavy metals in tomato, irrigation, magnetically-treated water, uptake of heavy metals.

\section{Introduction}

Magnetic treatment of irrigation water (magnetically-treated water) is a non-chemical method, environmentally-friendly and a new technology for agriculture that boosts crop yield [1], [2]. Magneticallytreated water is obtained when water flows through magnetic field at right angle to the field, the structure of the water is altered, reduction in bonding angle of water from 104 to $103^{\circ}$ and reduction in surface tension of the water. This modification in water properties increase minerals dissolvability of water for macro and micro elements in the soil and this provide adequate nutrients for plant growth [1], [3]. It also improves crop quality and increases minerals dissolvability of water for Calcium, Nitrogen, Potassium, iron and Lead which could enhance nutrients uptake by the crops [4], [5], [6], [7]. [8] indicated that magnetically-treated water significantly increased essential elements $(\mathrm{N}, \mathrm{P}, \mathrm{K})$ uptake when compared with plants irrigated with tap water (non magnetically-treated water). [9] also pointed out that magnetically-treated water (magnetized water) improved the Calcium, Iron, Potassium and Zinc contents in seeds of onion, sunflower and tomato fruit which significantly increased the production quality of the plants compared to non magnetically-treated water. 
Magnetically-treated water could also stimulate defense system, photosynthetic activity, and translocation efficiency of photoassimilates in common bean plants [10]. The uptake of the some elements such as Nitrogen, Calcium and Sulphur by tomato can improve the nutritional quality (like protein and vitamin C contents) of tomato. On the other hand, if magnetically-treated water increases uptake of heavy metals such Arsenic, Barium, Copper, Lead, Manganese and Zinc above the permissible limits of FAO/WHO and accumulation of the heavy metals could cause cancer and some other diseases to man after a prolong period of time. The objective of this study was to determine effect of irrigating tomato plant with magnetically-treated water on uptake of heavy metals by tomato fruit and yield of tomato.

Plants experience water deficit (irrigation deficit) when the irrigation requirement is not fully supplied and the crop is subjected to water shortage which could affect evapotranspiration, uptake of plant nutrients, photosynthesis and crop yield. [11] pointed out that magnetic treatment of irrigation water could alleviate adverse effect of water stress (water shortage) in crop because it reduces free radicals production and antioxidant enzymes activity. Magnetically-treated water increases evapotranspiration rate and water use efficiency [12]. This means that crop irrigated with magnetically-treated water could withstand water shortage, absorb little water available in the soil and the yield is not affected as crop irrigated with non magnetically-treated water.

The north and south poles of the electromagnetic cores on the treatment pipe were alternated for effective treatment of the irrigation water by the magnetic field as stated by [14] used a permanent magnet with magnetic field strength of $5500 \mathrm{G}(0.55 \mathrm{~T})$ to treat irrigation water and the effect was significant on growth and yield of okra that was irrigated with magnetically-treated water. [5] used magnetic flux density between 35 and $1360 \mathrm{G}$ which was measured inside the pipe. [15] pointed out that the residence time for treatment of irrigation water in magnetic field should be $15 \mathrm{~s}$ while [16] stated that 60 to $600 \mathrm{~s}$ was appropriate for effective magnetic treatment of irrigation water. The objectives of this study were to determine the effect of magnetically-treated water under water deficit conditions on tomato yield and uptake of some selected heavy metals by tomato fruit.

\section{Materials And Methods}

\subsection{Location of the Study}

The study was conducted twice at the Research Farm of the Department of Agricultural and Biosystems Engineering, University of Ilorin, Ilorin, Kwara State, Nigeria between $23^{\text {rd }}$ December, 2016 and $15^{\text {th }}$ July, 2017. Ilorin lies on the latitude $8^{\circ} 30^{\prime} \mathrm{N}$ and longitude $4^{\circ} 35^{\prime} \mathrm{E}$ at an elevation of about $340 \mathrm{~m}$ above mean sea level [17]. Ilorin is in the Southern Guinea Savannah Ecological Zone of Nigeria with annual rainfall of about 1,300 $\mathrm{mm}$. The wet season begins towards the end of March and ends in October while the dry season starts in November and ends in March [18].

\subsection{Chemical Properties of Soil used}

The chemical properties of soil used in the study were shown in Table 1. Sample A was the chemical properties of soil used in the first experiment which was conducted between 23rd December, 2016 and 18th March, 2017 (85 days) in which only the concentrations of some selected heavy metals in the tomato fruit were determined. Sample B was the chemical properties of soil used in the second experiment which was carried out between 23rd March and 15th July, 2017 (114 days) in which yield and concentrations of some selected heavy metals in the tomato were determined while the tomato plant was subjected to water deficit in which water was applied at different quantities. 
TABLE I: Chemical Properties of Soil used

\begin{tabular}{lcc}
\hline Element & Sample A & Sample B \\
\hline $\mathrm{pH}$ & 4.70 & 5.30 \\
$\mathrm{~N}(\%)$ & 0.80 & 1.00 \\
$\mathrm{P}(\mathrm{mg} / \mathrm{L})$ & 0.39 & 0.22 \\
$\mathrm{~K}^{+}(\mathrm{mg} / \mathrm{L})$ & 0.11 & 0.13 \\
$\mathrm{~Pb}^{2+}(\mathrm{mg} / \mathrm{L})$ & 1.80 & 1.30 \\
$\mathrm{Zn}^{2+}(\mathrm{mg} / \mathrm{L})$ & 0.90 & 0.80 \\
$\mathrm{Cr}^{2+}(\mathrm{mg} / \mathrm{L})$ & 0.14 & 0.07 \\
$\mathrm{Cu}^{2+}(\mathrm{mg} / \mathrm{L})$ & 0.54 & 0.55 \\
$\mathrm{Cd}^{2+}(\mathrm{mg} / \mathrm{L})$ & 0.01 & 0.01 \\
$\mathrm{Fe}^{2+}(\mathrm{mg} / \mathrm{L})$ & 8.50 & 8.70 \\
$\mathrm{Mn}^{2+}(\mathrm{mg} / \mathrm{L})$ & 0.55 & 0.60 \\
\hline
\end{tabular}

\subsection{Chemical Properties of Water used}

The water used in this study was obtained from University of Ilorin dam (at downstream, about $80 \mathrm{~m}$ away from the dam) and chemical properties of the water were presented in Table 2. The irrigation water was allowed to flow through a magnetic flux density of 319 gauss $(\mathrm{G})(31.9 \mathrm{mT})$ for about $113 \mathrm{~s}$ in a pipe. The equivalent magnetic flux density between two magnetic cores without air gap was 1,684 G. The magnetic field strength was measured inside the rectangular treatment pipe in which 2 magnetic cores was $20 \mathrm{~mm}$ apart using a gaussmeter, Model GM-2 by Alpha Lab Inc. The concentrations of some selected heavy metals for magnetically-treated water and non-magnetically-treated water (water before magnetically-treated) were analyzed and presented in Table 2.

TABLE II: Concentration of Some Selected Heavy Metals in the Water Used for Irrigation

\begin{tabular}{lccc}
\hline Element & WHO limits $(2001)$ & MTW & NMTW \\
\hline $\mathrm{Pb}^{2+}(\mathrm{mg} / \mathrm{L})$ & 5.00 & $\mathrm{ND}$ & $\mathrm{ND}$ \\
$\mathrm{Zn}^{2+}(\mathrm{mg} / \mathrm{L})$ & 2.00 & $\mathrm{ND}$ & $\mathrm{ND}$ \\
$\mathrm{Cr}^{2+}(\mathrm{mg} / \mathrm{L})$ & 1.00 & $\mathrm{ND}$ & $\mathrm{ND}$ \\
$\mathrm{Cu}^{2+}(\mathrm{mg} / \mathrm{L})$ & 0.20 & $\mathrm{ND}$ & $\mathrm{ND}$ \\
$\mathrm{Cd}^{2+}(\mathrm{mg} / \mathrm{L})$ & 0.01 & $\mathrm{ND}$ & 0.10 \\
$\mathrm{Fe}^{2+}(\mathrm{mg} / \mathrm{L})$ & 5.00 & $\mathrm{ND}$ & $\mathrm{ND}$ \\
$\mathrm{Mn}^{2+}(\mathrm{mg} / \mathrm{L})$ & 0.26 & \\
\hline
\end{tabular}

WHO = World Health Organisation, ND = Not detected, MTW = Magnetically-treated water, NMTW = Non magneticallytreated water.

\subsection{Determination of Crop Evapotranspiration, Volume of Water Requirement and Irrigation Interval}

Crop evapotranspiration is the amount of water that is needed to meet the required evapotranspiration, photosynthesis and metabolic processes. Crop evapotranspiration, depth of water required to bring the soil to field capacity at the beginning of the experiment, available water, wilting point, net depth of irrigation, irrigation interval and volume of water required daily by tomato plant and volume of water required in three (3) days irrigation interval by the tomato plant were determined using Equations (1), (2), (3), (4), (5), (6), (7) and (8), respectively.

$$
\begin{gathered}
E T_{c}=k_{c} \times E T_{o} \\
D_{F}=\frac{\rho_{b}}{\rho_{w}}\left(\frac{F C-\Theta_{1}}{100}\right) D_{b} \\
A W=\frac{\rho_{b}}{\rho_{w}}\left(\frac{F C-W P}{100}\right) D_{b}
\end{gathered}
$$




$$
\begin{gathered}
W P=\frac{F C}{F} \\
d_{n}=P_{n} \times A W \\
I_{v}=\frac{d_{n}}{E T_{c}} \\
V_{d}=C_{c} \times A_{b} \times E T_{c} \\
V_{i}=C_{c} \times A_{b} \times E T_{c} \times I_{v} \times N_{p}
\end{gathered}
$$

where $\mathrm{ET}_{\mathrm{c}}$ is the crop evapotranspiration $\left(\mathrm{mm} /\right.$ day), $\mathrm{k}_{\mathrm{c}}$ is the crop coefficient, $\mathrm{ET}_{\mathrm{o}}$ is the reference evapotranspiration (mm/day), $\mathrm{D}_{\mathrm{F}}$ is the depth of water required to bring moisture content to $\mathrm{FC}$ at the beginning of the experiment $(\mathrm{mm}), \rho_{\mathrm{b}}$ is the soil bulk density $\left(\mathrm{g} / \mathrm{cm}^{3}\right), \rho_{\mathrm{w}}$ is the density of water $\left(\mathrm{g} / \mathrm{cm}^{3}\right), \mathrm{FC}$ is the field capacity of the soil (\%), $\Theta$ is the initial moisture content of the soil prior to irrigation $(\%), \mathrm{D}_{\mathrm{b}}$ is the depth of the bucket or pot $(\mathrm{mm})$, Aw is the available water $(\mathrm{mm})$, WP is the wilting point $(\%), \mathrm{I}_{\mathrm{v}}$ is the irrigation interval (day), $d_{n}$ is the net depth of irrigation $(\mathrm{mm}), \mathrm{P}_{\mathrm{n}}$ is the percentage of available water to be supplied during irrigation (in fraction, $50 \%=0.5$ ), $\mathrm{C}_{\mathrm{c}}$ is the crop canopy but taken as $100 \%(1), \mathrm{V}_{\mathrm{d}}$ is the volume of water required by tomato plant (litre/day), $\mathrm{A}_{\mathrm{b}}$ is the area of the bucket $\left(\mathrm{m}^{2}\right), \mathrm{N}_{\mathrm{p}}$ is the number of plants that are to be irrigated and $\mathrm{V}_{\mathrm{i}}$ is the volume of water required by plant per irrigation (litre).

$\mathrm{F}$ in Equation (4) is a factor ranging from 2.0 - 2.4 depending on the percentage of silt in the soil [19]. The value of F used was 2.2 and WP was calculated to be $12.26 \%$ when FC was $26.98 \%$. The values of crop coefficient $\left(\mathrm{k}_{\mathrm{c}}\right)$ used was 1.15 because [20] indicated that $\mathrm{k}_{\mathrm{c}}$ of tomato at flowering stage was 1.15 . Reference evapotranspiration $\left(\mathrm{ET}_{\mathrm{o}}\right.$ ) of Ilorin for the North Central zone from the graph by Chineke et al. [21] for peak value during the month of March of the year is $5.5 \mathrm{~mm} /$ day and it was used in this study and $\mathrm{A}_{\mathrm{b}}$ of the bucket (pot) was equal to $0.05433 \mathrm{~m}^{2}$.

\subsection{Chemical Parameters Analyzed from Tomato}

Two samples of tomato fruits for each level of water applications were randomly harvested in the first and second experiments from magnetically-treated and non-magnetically-treated water after 65 and 95 days, respectively. The two samples of tomato fruits were obtained from tomato plant irrigated with 100, 80 and $60 \%$ of available water for the determination of concentrations of heavy metals in the tomato fruit. The heavy metals determined were Cadmium, Copper, Chromium, Iron II, Lead, Manganese, Nickel and Zinc.

\subsection{Determination of Lead Concentration and Other Heavy Metals}

The tomato was ground (wet tomato paste) and sieved through $2 \mathrm{~mm}$ sieve. A $2 \mathrm{~g}$ of the sample was weighed and heated to dryness in a well-cleaned porcelain crucible between 450 and $500{ }^{\circ} \mathrm{C}$ in a hot plate. The ash content was then dissolved in $5 \mathrm{ml} \mathrm{HNO}_{3}, \mathrm{HCL}$ and $\mathrm{H}_{2} \mathrm{O}$ in ratio of 1:2:3, respectively and this was heated on a hot plate until brown fume disappeared. A $5 \mathrm{ml}$ of deionized water was added and heated until a colourless solution was obtained. The mineral solution was transferred into $100 \mathrm{ml}$ volumetric flask and filtered through Whatman No 42 filter paper. This solution was then analyzed by Atomic Absorption Spectrophotometer (AAS) as given by [22]. The same procedure was used for digestion process and AAS was used to analyze other heavy metals as given by [22]. 


\subsection{Statistical Analysis on Yield of Tomato by CRD and Pair t-test}

\subsubsection{Statistical Analysis by Completely Randomized Design (CRD)}

Statistical analysis on the yield of tomato was computed to determine if the effects of magnetically-treated water and non-magnetically-treated water were statistically significant on the tomato yields or not using Completely Randomized Design (CRD). Sum of square treatment $\left(\mathrm{SST}_{\mathrm{R}}\right)$, Sum of square total $\left(\mathrm{SST}_{\mathrm{O}}\right)$, Correction factor (C.F) and Sum of square error $\left(\mathrm{SS}_{\mathrm{E}}\right)$ were computed using Equations (9), (10), (11) and (12), respectively. The Analysis of Variance (ANOVA) was based on values generated from Equations (9), (10) and (12).

$$
\begin{gathered}
S S T_{R}=\frac{\sum T_{i}^{2}}{t}-C . F \\
S S T_{O}=\sum X_{i}^{2}-C . F \\
C . F=\frac{G^{2}}{N} \\
S S_{E}=S S T_{O}-S S T_{R}
\end{gathered}
$$

where $T_{i}$ is the total yield of each treatment, $t$ is the number of treatments used, $X$ is the individual yield based on the treatment used, $\mathrm{G}$ is the total yield from all the treatments used and $\mathrm{N}$ is the number of observation which is equal to the product of number of treatments $(\mathrm{t})$ and number replications ( $\mathrm{r}$ )

\subsubsection{Statistical Analysis by Pair t-test}

A pair t-test statistical analysis was also computed between $T_{1}$ versus $T_{4}$ and $T_{2}$ versus $T_{4}$. The difference between the two mean of the results was determined and used to compute the standard deviation, standard error and t-test value using Equations (13), (14a) or (14b), (15) and (16), respectively as given by [23]. The calculated values of the t-test and that of table values were shown in Table 4.

$$
\begin{gathered}
\bar{d}=\frac{\sum d}{n} \\
\delta=\sqrt{\frac{\sum(d-\bar{d})^{2}}{n-1}} \\
\delta=\sqrt{\frac{\sum d^{2}-n(\bar{d})^{2}}{n-1}} \\
\delta_{E r}=\frac{\delta}{\sqrt{n}} \\
t_{c a l}=\frac{\bar{d}}{\delta_{E r}}
\end{gathered}
$$


where $\mathrm{d}$ is the mean of the difference from the data $\mathrm{x}_{1}$ and $\mathrm{x}_{2}, \Sigma \mathrm{d}$ is the summation of $\mathrm{d}, \mathrm{n}$ is the number of the treatments (observations), $\delta$ is the standard deviation, $\delta_{\mathrm{Er}}$ is the standard error and $\mathrm{t}_{\mathrm{cal}}$ is the calculated value of $t$ which was compared with the Table value of $t_{\text {Tab }}$ at $\alpha=5 \%$ significant level but $2.5 \%(\alpha=0.05 / 2=0.025)$ for paired t-test. For example, the tomato yield between MTW and NMTW extracted from Table 4 for pair t-test was computed as follows.

TABLE III: Data of Tomato Yield for Computation of Pair t-test

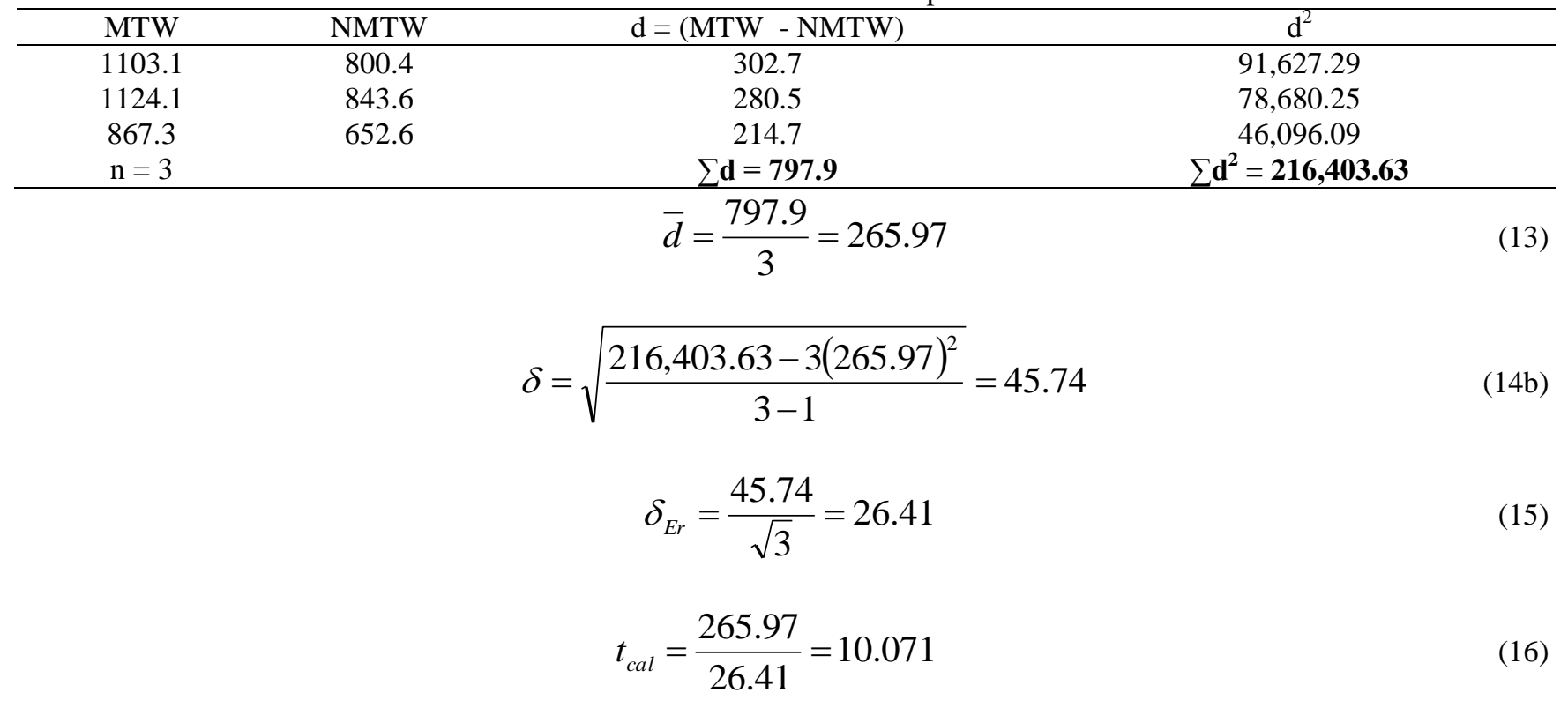

\section{Results And Discussion}

\subsection{Effect of Magnetically-Treated Water on Yield of Tomato Under Deficit Conditions}

The total and mean yields of tomato for magnetically-treated water (MTW) and non-magnetically-treated water (NMTW) under different water levels of application (under different water deficit conditions) of 100, 80 and $60 \%$ of available water supplied were presented in Table 4 . Tomato plant irrigated with $80 \%$ of water requirement gave the highest mean yield of $281.0 \mathrm{~g} /$ pot for MTW and $210.9 \mathrm{~g} / \mathrm{pot}$ for NMTW, followed by tomato plant irrigated with $100 \%$ with $275.8 \mathrm{~g} /$ pot for MTW and $200.1 \mathrm{~g} /$ pot for NMTW and the lowest tomato mean yield of $216.8 \mathrm{~g} /$ pot for MTW and $163.2 \mathrm{~g} /$ pot was obtained when $60 \%$ of water requirement was supplied to the plant. This means that water depletion by $40 \%$ of available water in tomato farm would lead to reduction in tomato yield. Tomato plant irrigated with MTW under the same water deficit produced higher tomato yield than the tomato plant irrigated with NMTW. The tomato yields from MTW when compared with yields from NMTW at 100, 80 and 60\% water applications, the yields were increased by $27.4 \%, 25.0 \%$ and $24.8 \%$, respectively. This means that MTW reduced the negative effect of water stress (water deficit) on the yield which agreed with the work by [10] that magnetically-treated water could also stimulate defense system, increased photosynthetic activity and enhanced translocation efficiency of photoassimilates in common bean plants. [11] also concluded that magnetic treatment of irrigation water could alleviate adverse effect of water stress (water deficit) in crop because it reduces free radicals production and antioxidant enzymes activity. [24] also found out that irrigating tomato plant by applying 100, 80, 60, 50 and 40\% of water requirement using MTW, the yields were increased by 38.0, 42.1, 93.0, 123.6 and $88.7 \%$, respectively when compared to the corresponding yields from NMTW using the same levels of water application of 100, 80, 60, 50 and 40\% water requirement.

The effect of water deficit on yields with Completely Randomized Design (CRD) for MTW and NMTW separately were not statistically significant on tomato because the calculated value of F for MTW was 0.62 and for NMTW was 0.79 while the Table value of F was $4.26(0.62<4.26$ and also $0.79<4.26)$ as shown in 
ANOVA Tables 5 and 6 for the CRD. In addition to that, a pair t-test statistical analysis was conducted to compare tomato yields from MTW and NMTW. The pair t-test showed that MTW had a significant effect on the yield of tomato when compared to the yield from NMTW with calculated value of t-test was 10.071 while Table value at $\alpha=5 \%(\alpha=0.05)$ but for pair t-test $\alpha=2.5 \%(\alpha=0.025)$ and at 2 degree of freedom was 6.205 . This means that the effect of MTW was statistically significant on the yield of tomato in this study because calculated value of pair t-test was 10.071 which was greater than the Table value of t-test 6.205 .

\subsection{Effect of Magnetically-Treated Water on Uptake of Heavy Metals by Tomato Fruit}

Uptake of heavy metals by the tomato was assessed based on the concentration of heavy metals in the tomato fruit. In the first experiment conducted, the mean concentrations of Cadmium, copper, Chromium, Iron II, Lead, Manganese and Zinc for MTW and NMTW in which $100 \%\left(\mathrm{~T}_{1}\right)$ and $80 \%\left(\mathrm{~T}_{2}\right)$ of water requirements were supplied, the results of some selected heavy metals were presented in Table 7. The concentrations of heavy metals in the second experiment for MTW and NMTW in which 100\% $\left(\mathrm{T}_{1}\right), 80 \%\left(\mathrm{~T}_{2}\right)$ and $60 \%\left(\mathrm{~T}_{3}\right)$ of water requirement were supplied, the results of the heavy metals were presented in Table 8 .

In the first experiment with the results shown in Table 7, Cadmium and Chromium were not detected (negligible) but values of Copper, Iron, Lead, Manganese and Zinc with MTW for $\mathrm{T}_{1}$ and $\mathrm{T}_{2}$, the range were $0.02-0.03,1.2-1.8,0.03-0.07,0.10-0.12$ and $0.00-0.01 \mathrm{mg} / \mathrm{L}$, respectively. The corresponding values for NMTW were $0.02-0.02$, 1.30-1.60, 0.04-0.04, 0.08-0.11 mg/L but $\mathrm{Zn}$ was not detected.

In the second experiment in Table 8, the concentrations of Lead for $T_{1}, T_{2}$ and $T_{3}$ for MTW were 0.015, 0.010 , and $0.010 \mathrm{mg} / \mathrm{L}$ and the corresponding values for NMTW were $0.015,0.010$, and $0.010 \mathrm{mg} / \mathrm{L}$, respectively. The mean concentrations of Zinc in the tomato fruit for $\mathrm{T}_{1}, \mathrm{~T}_{2}$ and $\mathrm{T}_{3}$ irrigated with MTW were $0.110,0.015$ and 0.010 while the corresponding values for NMTW were $0.125,0.110$ and $0.135 \mathrm{mg} / \mathrm{L}$, respectively. This means that NMTW increased uptake of Zinc in the tomato than the tomato plant irrigated with MTW as shown in Table 8. Concentrations of Iron II for both MTW and NMTW were the same with 0.010 $\mathrm{mg} / \mathrm{L}$ except for $60 \%$ water deficit that had $0.045 \mathrm{mg} / \mathrm{L}$. Therefore, MTW slightly increased uptake of Lead, Copper and Iron II by 42.9, $42.977 .8 \%$, respectively especially when water was supplied at $80 \%$ and $60 \%$ of water requirements. This was in agreement with the work conducted by some researchers that magneticallytreated water resulted in the increased in Nitrogen, Phosphorous and Potassium uptake and their translocation in plant [8]. [25] also concluded that magnetically-treated irrigation water increased available soil Phosphorous in celery and snow pea. Concentrations of Cadmium, Manganese and Nickel in tomato were not detected. From the two experiments conducted, concentrations of all the heavy metals assessed in this study were below [26] and [27] permissible limits. Magnetically treated water (magnetized water) increased tomato yield and did not add heavy metals to tomato fruit that could make the tomato fruit toxic for consumption cause certain diseases as stated by [28].

TABLE IV: Total and Mean Yields of Tomato from Magnetically-Treated and Non-Magnetically-

Treated Water

Total and mean yield of tomato $(\mathrm{g} / \mathrm{pot})$

\begin{tabular}{ccccccc} 
Row & \multicolumn{3}{c}{ Magnetically-treated water } & \multicolumn{3}{c}{ Non magnetically-treated water } \\
& $\mathrm{T}_{1}$ & $\mathrm{~T}_{2}$ & $\mathrm{~T}_{3}$ & $\mathrm{~T}_{1}$ & $\mathrm{~T}_{2}$ & $\mathrm{~T}_{3}$ \\
\hline 1 & 168.9 & 390.7 & 265.8 & 165.4 & 233.1 & 133.4 \\
2 & 390.7 & 236.8 & 261.7 & 305.2 & 186.8 & 182.1 \\
3 & 231.8 & 261.7 & 247.2 & 146.6 & 204.7 & 241.6 \\
4 & 311.6 & 234.9 & 97.7 & 183.2 & 219.0 & 95.5 \\
Total yield & $\mathbf{1 1 0 3 . 1}$ & $\mathbf{1 1 2 4 . 1}$ & $\mathbf{8 6 7 . 3}$ & $\mathbf{8 0 0 . 4}$ & $\mathbf{8 4 3 . 6}$ & $\mathbf{6 5 2 . 6}$ \\
Mean yield & $\mathbf{2 7 5 . 8}$ & $\mathbf{2 8 1 . 0}$ & $\mathbf{2 1 6 . 8}$ & $\mathbf{2 0 0 . 1}$ & $\mathbf{2 1 0 . 9}$ & $\mathbf{1 6 3 . 2}$ \\
\hline
\end{tabular}

$\mathrm{T}_{1}=100 \%$ of water requirement was supplied, $\mathrm{T}_{2}=80 \%$ of water requirement was supplied $\mathrm{T}_{3}=60 \%$ of water requirement was supplied 
TABLE V: Analysis of Variance (ANOVA) of the Tomato Yield for MTW with CRD

\begin{tabular}{|c|c|c|c|c|c|}
\hline Source of error & (D.F) & Sum of square (SS) & Mean square (MS) & Calculated $\mathrm{F}$ & $\begin{array}{c}\text { Tabular F at } \\
P \leq 5 \%\end{array}$ \\
\hline Treatment & 2 & $10,165.74$ & $5,082.87$ & $0.62^{\mathrm{NS}}$ & 4.26 \\
\hline Error & 9 & $73,685.17$ & $8,187.24$ & & \\
\hline Total & 11 & $63,518.43$ & 5774.9 & & \\
\hline
\end{tabular}

NS = Not significant, MTW = Magnetically-treated water, CRD as previously defined

TABLE VI: Analysis of Variance (ANOVA) of the Tomato Yield for NMTW with CRD

\begin{tabular}{ccccc}
\hline Source of error & $\begin{array}{c}\text { Degree of freedom } \\
\text { (D.F) }\end{array}$ & Sum of square (SS) & Mean square (MS) & $\begin{array}{c}\text { Calculated F } \\
\text { Tabular F at } \\
\text { P } \leq 5 \%\end{array}$ \\
\hline Treatment & 2 & $5,016.01$ & $2,508.01$ & $0.79^{\text {NS }}$ \\
Error & 9 & $28,550.75$ & $3,172.33$ & \\
Total & 11 & $33,566.76$ & 3051.52 & \\
\hline
\end{tabular}

NS = Not significant, NMTW = Non magnetically-treated water

TABLE VII: Concentrations of Heavy Metals in Tomato in the First Experiment

\begin{tabular}{|c|c|c|c|c|c|c|c|}
\hline \multirow[t]{4}{*}{ Heavy metal } & \multicolumn{6}{|c|}{ Concentration of heavy metals in the tomato $(\mathrm{mg} / \mathrm{L})$} & \multirow{4}{*}{$\begin{array}{l}\text { Health implication on man } \\
\text { according to SON Act } 2007\end{array}$} \\
\hline & \multirow{2}{*}{\multicolumn{2}{|c|}{$\begin{array}{l}\text { Magnetized } \\
\text { water }\end{array}$}} & \multirow{2}{*}{\multicolumn{2}{|c|}{ Non-magnetized water }} & \multirow{3}{*}{$\begin{array}{l}\text { WHO } \\
2003 \\
\text { limits }\end{array}$} & \multirow{3}{*}{$\begin{array}{c}\text { FAO } 1985 \\
\text { limits }\end{array}$} & \\
\hline & & & & & & & \\
\hline & $\mathrm{T}_{1}$ & $\mathrm{~T}_{2}$ & $\mathrm{~T}_{1}$ & $\mathrm{~T}_{2}$ & & & \\
\hline Cadmium & ND & ND & ND & ND & 0.01 & 0.01 & Toxic to kidney \\
\hline Copper & 0.02 & 0.03 & 0.02 & 0.02 & 0.20 & 0.20 & Gastrointestinal disorder \\
\hline Chromium & ND & ND & ND & ND & 1.00 & 1.00 & Cancer \\
\hline Iron II & 1.80 & 1.20 & 1.60 & 1.30 & 5.00 & 5.00 & None \\
\hline Lead & 0.03 & 0.07 & 0.04 & 0.04 & 5.00 & 5.00 & $\begin{array}{l}\text { Cancer, mental retardation in } \\
\text { children, toxic to central and } \\
\text { peripheral nervous systems }\end{array}$ \\
\hline Manganese & 0.12 & 0.10 & 0.08 & 0.11 & 0.26 & - & Neurological disorder \\
\hline Nickel & ND & ND & ND & ND & 1.00 & 0.20 & Possible carcinogenic \\
\hline Zinc & 0.01 & ND & ND & ND & 2.00 & 2.00 & None \\
\hline
\end{tabular}

$\mathrm{T}_{1}=100 \%$ of water requirement was supplied, $\mathrm{T}_{2}=80 \%$ of water requirement was supplied

ND = Not detected, SON = Standards Organisation of Nigeria for Drinking Water Quality

$\mathrm{FAO}=$ Food and Agriculture Organisation of the United Nations,

WHO = World Health Organisation

TABLE VIII: Concentrations of Heavy Metals in the Tomato in the Second Experiment

\begin{tabular}{|c|c|c|c|c|c|c|c|}
\hline \multirow{3}{*}{ Heavy metal } & \multicolumn{6}{|c|}{ Concentration of heavy metals in the tomato fruit $(\mathrm{mg} / \mathrm{L})$} & \multirow{3}{*}{$\begin{array}{c}\text { WHO limits } 2003 \\
(\mathrm{mg} / \mathrm{L})\end{array}$} \\
\hline & \multicolumn{3}{|c|}{ Magnetically-treated water } & \multicolumn{3}{|c|}{ Non magnetically-treated water } & \\
\hline & $\mathrm{T}_{1}$ & $\mathrm{~T}_{2}$ & $\mathrm{~T}_{3}$ & $\mathrm{~T}_{1}$ & $\mathrm{~T}_{2}$ & $\mathrm{~T}_{3}$ & \\
\hline \multirow{2}{*}{ Cadmium } & ND & ND & ND & ND & ND & ND & \\
\hline & ND & ND & ND & ND & ND & ND & 0.02 \\
\hline \multirow[t]{2}{*}{ Copper } & ND & ND & 0.030 & ND & ND & 0.030 & \\
\hline & ND & 0.050 & ND & ND & ND & ND & \\
\hline Mean & ND & $\mathbf{0 . 0 5 0}$ & 0.030 & ND & ND & 0.030 & 1.00 \\
\hline \multirow[t]{2}{*}{ Iron II } & 0.010 & 0.010 & 0.040 & 0.010 & 0.010 & 0.010 & \\
\hline & 0.010 & 0.010 & 0.050 & 0.010 & 0.010 & 0.010 & \\
\hline Mean & 0.010 & 0.010 & 0.045 & 0.010 & 0.010 & 0.010 & 5.00 \\
\hline \multirow[t]{2}{*}{ Lead } & 0.010 & 0.010 & 0.040 & 0.010 & 0.010 & 0.010 & \\
\hline & 0.010 & 0.010 & 0.050 & 0.010 & 0.010 & 0.010 & \\
\hline Mean & 0.010 & 0.010 & 0.045 & 0.010 & 0.010 & 0.010 & 0.26 \\
\hline \multirow[t]{2}{*}{ Manganese } & ND & ND & ND & ND & ND & ND & \\
\hline & ND & ND & ND & ND & ND & ND & 0.01 \\
\hline \multirow[t]{2}{*}{ Nickel } & ND & ND & ND & ND & ND & ND & \\
\hline & ND & ND & ND & ND & ND & ND & 1.00 \\
\hline \multirow{2}{*}{ Zinc } & 0.110 & 0.020 & 0.010 & 0.140 & 0.110 & 0.160 & \\
\hline & 0.110 & 0.010 & 0.010 & 0.110 & 0.110 & 0.110 & \\
\hline Mean & 0.110 & 0.015 & 0.010 & 0.125 & 0.110 & 0.135 & 2.00 \\
\hline
\end{tabular}

$\mathrm{T}_{1}=100 \%$ of water requirement was supplied, $\mathrm{T}_{2}=80 \%$ of water requirement was supplied

$\mathrm{T}_{3}=60 \%$ of water requirement was supplied, ND and WHO are as previously defined in Table 7 
Magnetically-treated water reduced effect of water deficit on tomato yield and tomato yields at 100, 80 and $60 \%$ water applications were increased by $27.4 \%, 25.0 \%$ and $24.8 \%$, respectively. Tomato plant irrigated with magnetically-treated water at 80 and $60 \%$ of water requirement had higher concentrations of heavy metals than when $100 \%$ of water requirement was supplied. Magnetically-treated water did not add or significantly increased uptake of heavy metals to tomato fruit which could be harmful to man. All the concentrations of heavy metals in the tomato were below FAO/WHO permissible limits.

\section{Recommendation}

Magnetically-treated water (Magnetic treatment of irrigation water) is a non-chemical method and environmentally-friendly that boosts crop yield should be adopted and use for crop production. More research should be conducted on the uptake of heavy metals by crops irrigated with magnetically-treated water in areas having high concentration of heavy metals.

\section{References}

[1] C. Babu. "Use of magnetic water and polymer in agriculture". Tropical Research, 2010, ID 08-806-001.

[2] K.O Yusuf and A.O Ogunlela, "Effects of magnetized water on the vegetative growth and yield of tomato". Agricultural Engineering International: CIGR Journal, 2017, Vol 19 No 1, pp: 1-8.

[3] A.O. Ogunlela and K.O. Yusuf, "Effect of magnetic treatment of water on chemical properties of water and sodium adsorption ratio". Journal of Research in Forestry, Wildlife and Environment, 2016, Vol. 8 No 4, pp; 73 - 79.

[4] M.M. Selim, "Application of Magnetic Technologies in Correcting Under Ground Brackish Water for Irrigation in the Arid and Semi-Arid Ecosystem". The $3^{\text {rd }}$ International Conference on Water Resources and Arid Environments, and the $1^{\text {st }}$ Arab Water Forum, held at King Fahd Cultural Centre, Riyadh, Saudi Arabia. 2008, pp: 1-11.

[5] R.L. Maheshwari, and H. S. Grewal. "Magnetic treatment of irrigation water: its effects on vegetable crop yield and water productivity”. Journal of Agricultural Water Management, 2009, Vol. 96 No 8 pp. 1229 -1236.

[6] M. Hozayn and A. M. S. Abdul-Qados, "Irrigation with magnetized water enhances growth, chemical constituent and yield of chickpea (Circer arietinum L.)". Agriculture and Biology Journal of North America, 2010. Vol. No 14, pp. 671-676.

[7] K.O. Yusuf and A.O. Ogunlela, "Effect of magnetically treated water on the quality of tomato. Kathmandu University Journal of Science, Engineering and Technology, 2016, Vol.12 No 2, pp. 29-33.

[8] H. Rawabdeh, S. Shiyab and R. Shibli, "The Effect of Irrigation by Magnetically Chlorophyll and Macroelements uptake of Pepper (Capsicum annuum L.)". Jordan Journal of Agricultural Sciences, 2014, Vol. 10 No 2, pp. 205-214.

[9] A.A.M. ELshokali and A.M. Abdelbagi, "Impact of magnetized water on elements contents in plants seeds". International Journal of Scientific Research and Innovative Technology, 2014. Vol. 1 No 4, pp. 12 - 21.

[10] H.R. Moussa, "The impact of magnetic water application for improving common bean (Phaseolus vulgaris L.) production”. New York Science Journal, 2011, Vol. 4 No 6, pp. 15-20.

[11] A. Anand, S. Nagarajan, A.P.S. Verma, D.K.Joshi, P.C. Pathak, and J. Bhardwaj, "Pre-treatment of seeds with static magnetic field ameliorates soil water stress in seedling of maize (Zea mays L.)". Indian Journal of Biochemistry and Biophysics, 2012, Vol. 49 No 1, pp. 63 - 70.

[12] K.O. Yusuf and A. O. Ogunlela, "Effect of magnetic treatment of water on evapotranspiration of tomato". Arid Zone Journal of Engineering, Technology and Environment, 2017, Vol. 13 No 1, pp. 86 - 96.

[13] C.A. McMahon, "Investigation of the quality of water treated by magnetic fields". B. Eng Thesis University of Southern Queensland, 2006. 
[14]C.C. Chern, "Application of magnetic water to stimulate the lady's finger (Abelmosculentus L.) moench plant growth". B. Eng. Thesis submitted to Faculty of Civil Engineering, University of Technology, Malaysia, 2012.

[15] J. Podlesny, S. Pietruszewski, and A. Podleoena, "Efficiency of the magnetic treatment of broad bean seeds cultivated under experimental plot conditions". Int. Agrophysics, 2004, Vol. No 18, pp. 65 - 71.

[16] A. Aladjadjiyan, "The use of physical methods for plant growing stimulation in Bulgaria". Journal of Central European Agriculture, 2007, Vol. 8 No 3, pp. 369-380.

[17]C.J. Ejieji and K.A. Adeniran, "Effect of water and fertilizer stress on the yield, fresh and dry matter production of grain amaranth. Australian Journal of Agricultural Engineering, 2009, Vol. 1 No 1, pp.18-24.

[18] A.O. Ogunlela, "Stochastic analysis of rainfall event in Ilorin, Nigeria. Journal of Agricultural Research and Development. Nigeria, 2001, pp. 39-49.

[19] M. Sani, "The effect of moisture stress on yield of maize intercropped with cowpea". Unpublished B. Eng Project report submitted to the Department of Agricultural and Biosystems Engineering, University of Ilorin, Ilorin, Nigeria, 2003.

[20] G.C. Ufoegbune, N.J. Bello, O.F. Dada, A.C. Eruola, A.A. Makinde and A.A. Amori, "Estimating water availability for agriculture in Abeokuta south western Nigeria”. Global Journal of Science Frontier Research Agricultural and Veterinary Sciences, 2012, Vol. 12 No 9, pp. 13 - 24.

[21]T.C. Chineke, M. E. Idinoba, and O. C. Ajayi, "Seasonal evapotranspiration signatures under a changing land scope and ecosystem management in Nigeria: implication for agriculture and food security”. American Journal of Scientific and Industrial Research, 2011, Vol. 2 No 2, pp. 191-204.

[22] AOAC, "Official Methods of Analysis of the Association of Official Analytical Chemists" 15th Edition, Arlington, Virginia, USA, 2000.

[23]D.C. Montgomery, G.C. Runger, N.F. Hubele, "Engineering statistics”. John Wiley and Sons, Inc, New York. 1998, 135 $-248$.

[24] A.O. Ogunlela and K.O. Yusuf, "Effects of water stress on growth and yield of tomato irrigated with magnetically treated water". Nigerian Journal of Pure and Applied Sciences. 2016, Vol. 29 No 2, pp. 2921 - 2932.

[25] A.I. Mohammed and B.M. Ebead, "Effect of irrigation with magnetically treated water on faba bean growth and composition”. International Journal of Agricultural Policy and Research, 2013, Vol.1 No 2, pp/ 24 - 40.

[26] FAO, "Water quality for irrigation for agriculture". Irrigation Drainage Paper, 1985, Vol. 29, pp. 1-130.

[27] WHO “Guidelines for Drinking Water Quality”, WHO, Geneva, 2003, pp. 90-120.

[28] SON, "Nigerian Standard for Drinking Water quality”. 2007, pp. 1 - 30. 